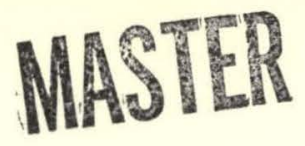

\title{
A Review of the Literature on Leachates from Coal Storage Piles
}

\author{
E. C. Davis \\ W. J. Boegly, Jr.
}

OAK RIDGE NATIONAL LABORATORY OPERATED BY UNION CARBIDE CORPORATION - FOR THE DEPARTMENT OF ENERGY 


\section{DISCLAIMER}

This report was prepared as an account of work sponsored by an agency of the United States Government. Neither the United States Government nor any agency Thereof, nor any of their employees, makes any warranty, express or implied, or assumes any legal liability or responsibility for the accuracy, completeness, or usefulness of any information, apparatus, product, or process disclosed, or represents that its use would not infringe privately owned rights. Reference herein to any specific commercial product, process, or service by trade name, trademark, manufacturer, or otherwise does not necessarily constitute or imply its endorsement, recommendation, or favoring by the United States Government or any agency thereof. The views and opinions of authors expressed herein do not necessarily state or reflect those of the United States Government or any agency thereof. 


\section{DISCLAIMER}

Portions of this document may be illegible in electronic image products. Images are produced from the best available original document. 


\begin{tabular}{|c|}
\hline Printed in the United States of America. Available from \\
National Technical Information Service \\
U.S. Department of Commerce \\
5285 Port Royal Road, Springfield, Virginia 22161 \\
Price: Printed Copy $\$ 5.25 \div$ Microfiche $\$ 3.00$
\end{tabular}

This report was prepared as an account of work sponsored by an agency of the United States Government. Neither the United States Government nor any agency thereof, nor any of their employees, contractors, subcontractors, or their employees, makes any warranty, express or implied, nor assumes any legal liability or responsibility for any third party's use or the results of such use of any information, apparatus, product or process disclosed in this report, nor represents that its use by such third parly wuuld not.infringe privately owned rights. 
Contract No. W-7405-eng-26

A REVIEW OF THE LITERATURE ON LEACHATES

FROM COAL STORACE PILES

E. C. Davis
Vanderbilt University ${ }^{66}{ }^{0^{\circ}}$
W. J. Boegly, Jr.
Environmental Sciences Division ${ }_{483^{3}} 20^{\circ 0}$

January 1978

Fossi.1. Energy Environmental Project

C. R. Booton, Program Manager

OAK RIDGE NATIONAL LABORATORY

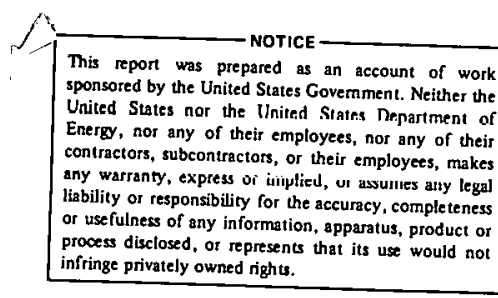

Oak Ridge, Tennessee .37830 operated by

UNION CARBIDE CORPORATION

for the

DEPARTMENT OF ENERGY 


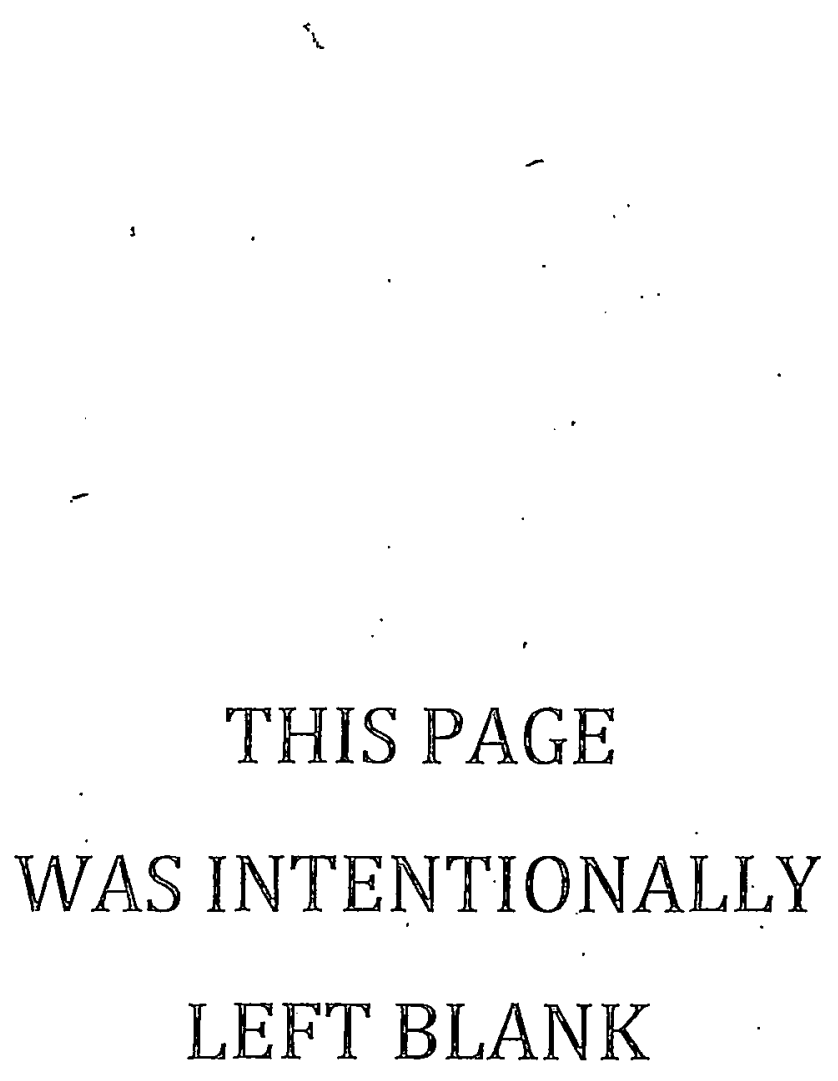


LIST OF FIGURES . . . . . . . . . . . . . . . . . . . v v

LIST OF TABLES . . . . . . . . . . . . . . . . . . . vii

ABSTRACT . . . . . . . . . . . . . . . . . . . . 1

INTRODUCTION . . . . . . . . . . . . . . . . . . 1

Coal and the National Energy Outlook . . . . . . . . 2

Environmental Protection Agency Steam-Electric Power

Plant Effluent Guidelines . . . . . . . . . . . 6

Storage of Coal . . . . . . . . . . . . . . 9

LITERATURE REVIEW - COAL PILE LEACHATE . . . . . . . . . . . 12

SUMMARY . . . . . . . . . . . . . . . . . . . . 32

CONCLUSIONS . . . . . . . . . . . . . . . . . 33

REFERENCES . . . . . . . . . . . . . . . . . . . . 34 


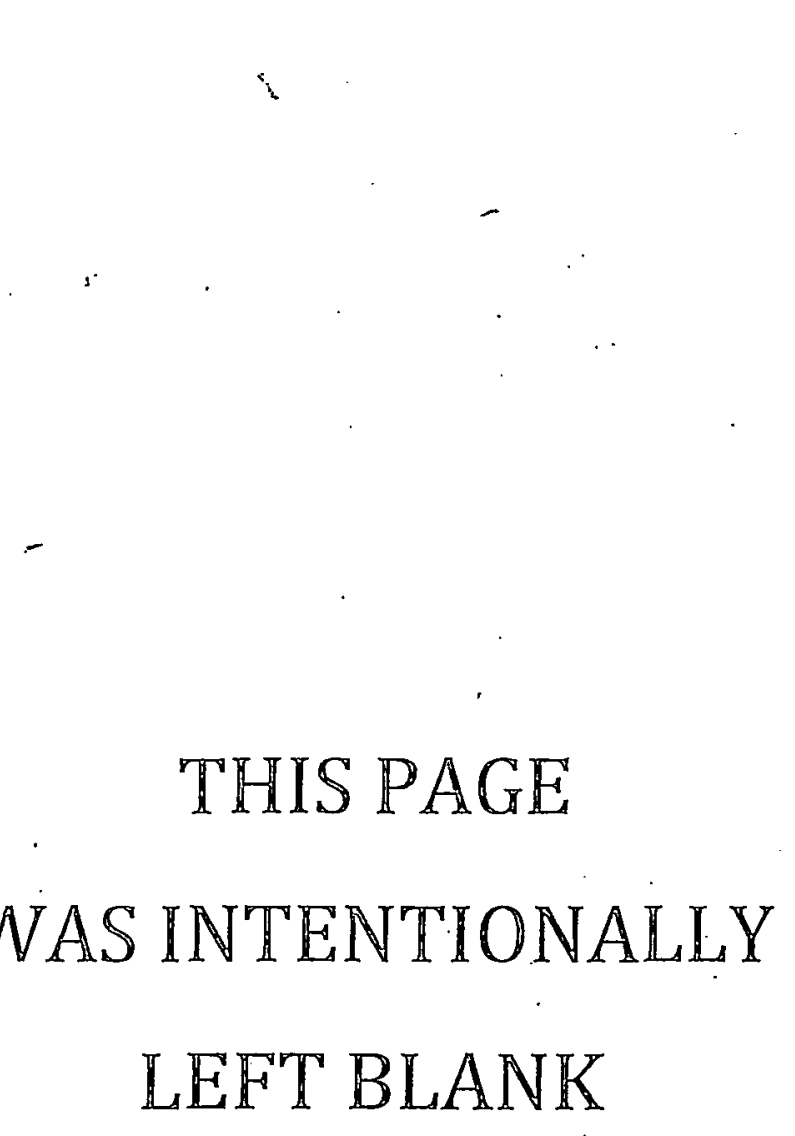

\section{WAS INTENTIONALLY}

LEFT BLANK 


\section{LIST OF FIGURES}

\section{Figure}

Page

1. Proved reserves economically recoverable with existing technology . . . . . . . . . . . . . . . . .

2. Projected energy supply pattern for all energy uses with and without NEP . . . . . . . . . . . . . . . 4

3. Cross section of a compacted coal pile . . . . . . . . 11

4. U.S. proposed and existing coal slurry pipelines . . . . . 30 


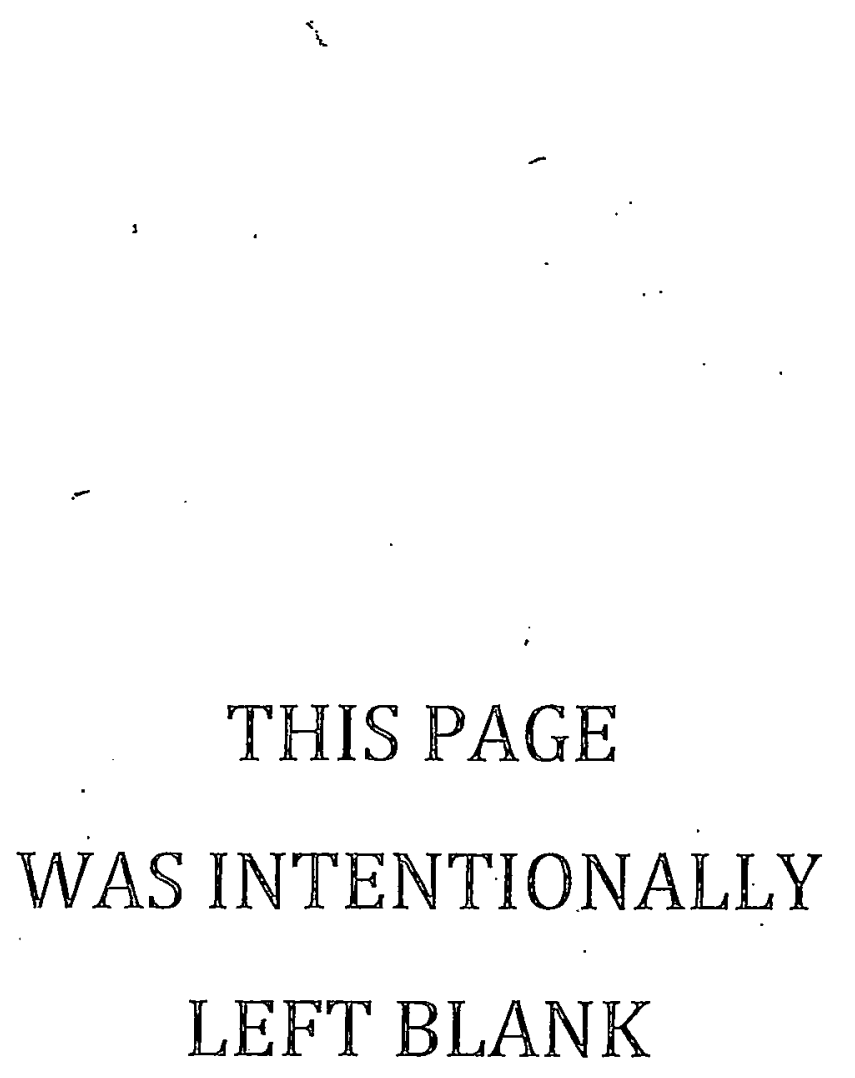


1. Projected energy supply pattern . . . . . . . . . 5

2. Maximum contaminant levels for inorganic chemicals allowed in public water supplies . . . . . . . . . 6

3. Discharge limits for steam-electric plants . . . . . . 8

4. EPA survey results - coal plle leachate quality . . . . . 14

5. Summary of leachate quality . . . . . . . . . . 15

6. Summary of leachate under wet aerobic, intermediate aerobic, and anaerobic conditions . . . . . . . . 17

7. Trace-element content of American coals . . . . . . . 18

8. Distribution of environmentally hazardous trace elements . . 18

9. Coal pile leachate data from TVA plants $J$ and E . . . . . 19

10. Trace-metal data from TVA plants J and E . . . . . . . 21

11. Characteristics of coal pile drainage . . . . . . . . 22

12. Coal pile runoff analysis at selected plants . . . . . . 24

13. Average analysis of base flow coal pile drainage . . . . . 26

14. Maximum and minimum concentrations of trace constituents of coal pile drainage . . . . . . . . . . . . . 26

15. Analysis of effluents from refuse piles . . . . . . . . 29 


\section{A REVIEW OF THE LITERATURE ON LEACHATES}

FROM COAL STORAGE PILES

E. C. Davis W. J. Boegly, Jr.

\section{ABSTRACT}

Runoff from coal storage piles associated with coal conversion or combustion factlities may represent a potential source of environmental pollution. This report is an assessment of existing information on coal pile leachate. The assessment indicates that few detalled studies have been conducted to date, and these are limited and the results are highly variable. More detailed long-range studies using various types of coal are recommended. These studies should be carried out both in the laboratory and in field-scale experiments.

\section{INTRODUCTION}

Disposal of coal conversion solid waste and ash may not be the only source of pollutants from coal conversion and combustion plants. Leachate from coal storage piles also represents a source of trace elements and organic compounds which environmental engineers will be forced to contend with in the future.

Many utilities and smaller power plants in the United States will be undergoing a conversion from oil and gas to coal in the light of recommendations made in the National Energy Plan (U.S. Government 1977). This plan states that resources in plentiful supply should be used more widely as part of a process of moderating the use of those in short supply. Although coal comprises $90 \%$ of U.S. total fuel reserves, the U.S. meets only $18 \%$ of its energy needs from coal (see Fig. 1). Seventy-five percent of energy needs are currently being met by oil and natural gas, although they account for less than $8 \%$ of U.S. reserves. This Imbalance between reserves and consumption should be corrected by shffting industrial and utility consumption from oil and gas to coal and other abundant energy 


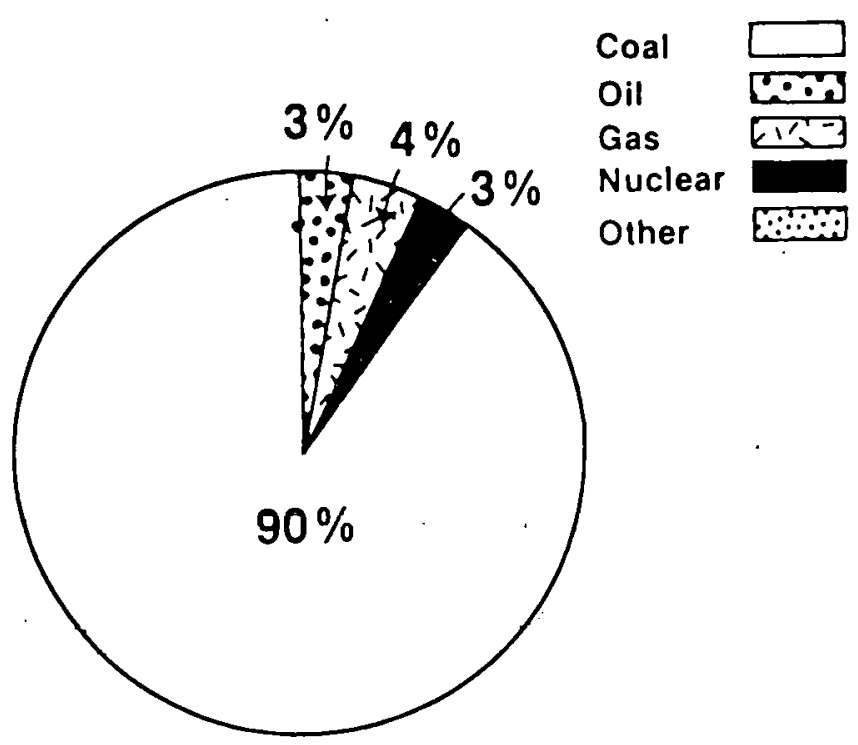

Fig. 1. Proved reserves economically recoverable with existing technology. Source: Federal Energy Administration 1976.

sources. It is this conversion from scarce gas and oil supplies to more abundant coal supplies which has spurred research interest in the environmental effects of coal storage pile leachate.

The Oak Ridge National Laboratory, Fnssi1. Fnergy Environmental Project (ORNL-FEEP), has an experimental program dealing with environmental aspects of leachate from.stored solids on the plant site. One phase of the ORNL-FEEP effort is to determine to what extent leachate from coal storage piles represents a potential pollution problem. The major purpose of this report is to review existing information on leachate from coal storage piles and to make a preliminary assessment of the need for further research. In addition to the literature review, a short summary of the national energy outlook, power plant effluent guidelines, and present coal storage pile practices is presented to set the stage for the specific review.

Coal and the National Energy Outlook

The nation's coal industry began in the 18 th century with bituminous coal mined in Virginia and anthracite in Pennsylvania. Coal production increased steadily throughout the 19 th century to meet the demand for 
uses such as space heating, coal gas, steam generation, and coke for steel production. By the turn of this century, coal supplied $90 \%$ of the U.S. energy consumption (Federal Energy Administration 1976). However, during the first half of this century, coal consumption grew less rapidly than total energy consumption because more convenient and competitively priced domestic oil and natural gas became available. Also, new uses of oil (e.g., automobiles) expanded rapidly. By 1950, coal dropped to $38 \%$ of the nation's energy consumption while coal production remained steady.

In April 1977, President Carter introduced the National Energy Plan (NEP), which may be summarized by the following five major goals:

1. reduce U.S. dependence on oil imports and vulnerability to interruptions of foreign oil supply;

2. lower the rate of growth of total U.S. energy demand and make the U.S. stock of capital goods more energy efficient;

3. shift industrial and utility consumption of oil and natural gas to coal and other abundant resources;

4. provide incentives for new oil and natural gas discoveries;

5. advance the development of new energy sources for the 1ong-term future.

Under the NEP, the rate of energy demand growth is projected to increase at $2.6 \%$ annually between 1975 and 1985 and at $0.6 \%$ from 1985 to 2000. Without the conservation initiatives postulated by the NEP, energy consumption is projected to inrrease by $3,2 \%$ annually between 1975 and 1985 and by $2.3 \%$ each year thereafter through 2000 . Based on these growth rates, the NEP calls for an energy supply of 123.5 quadrillion Btu's (quads) to meet demands in the year 2000, whereas without NEP, projections lead to 139.8 quads of production, a $13.2 \%$ increase over the NEP.

Pre NEP projoctions show that at current consumption levels, there are enough coal reserves to last at least 300 years, and at projected 1985 consumption levels, there is enough to last at least 200 years (FEA 1976). Figure 2 and Table 1 show the projections of how the U.S. will meet its growing energy demands (ERDA 1977). 

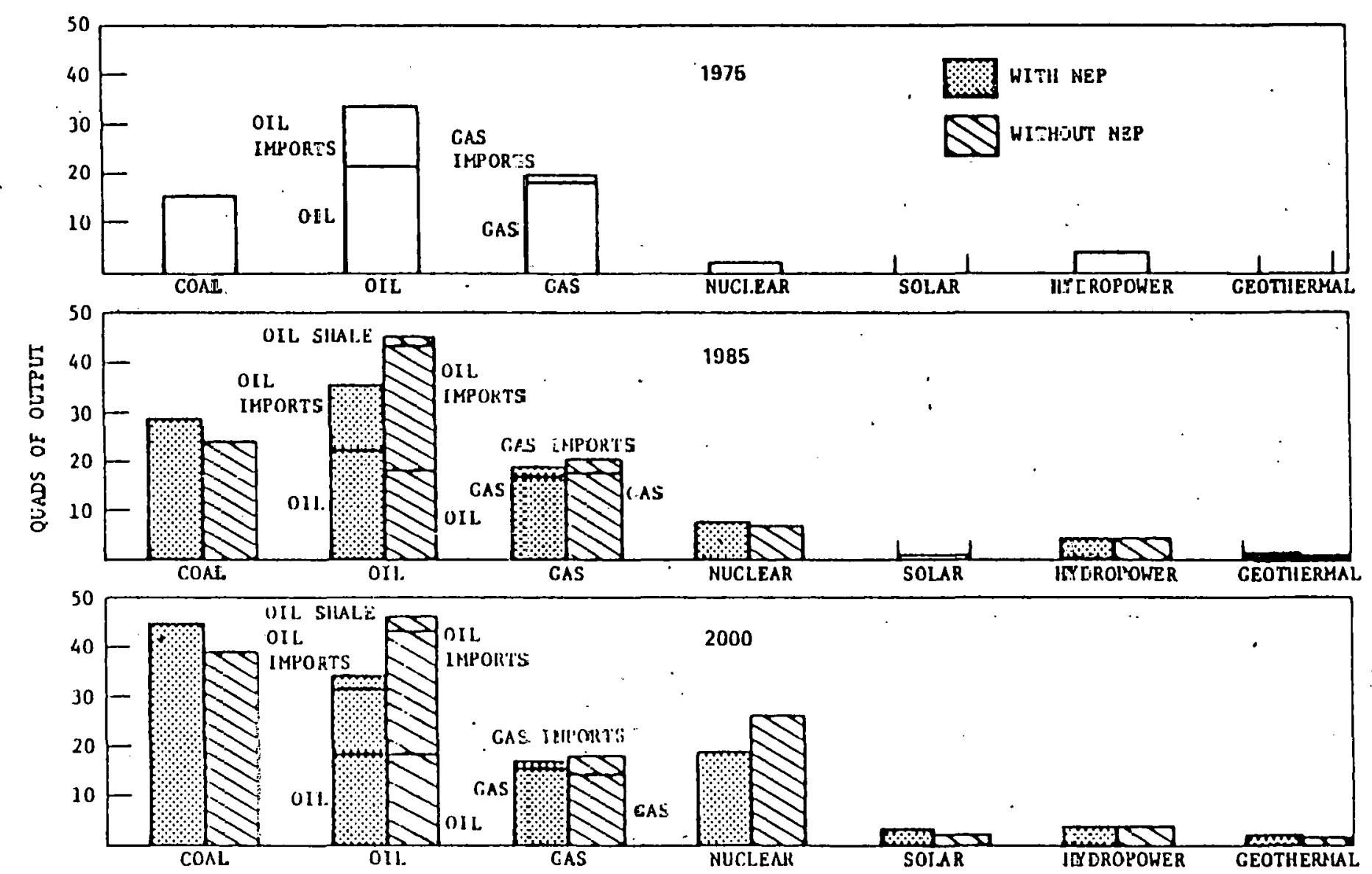

Fig. 2. Projected energ: suppls pattern for all energy uses with and without NEP. Source: ERDA 1977. 
Table 1. Profected energy supply pattern (quads)

\begin{tabular}{|c|c|c|c|c|c|}
\hline \multirow[b]{2}{*}{ Energy source } & \multirow[b]{2}{*}{1975} & \multicolumn{2}{|c|}{1985} & \multicolumn{2}{|c|}{2000} \\
\hline & & NEP & Pre-NEP & NEP & Pre-NEP \\
\hline Coal & 15.3 & 28.2 & 23.9 & 44.9 & 38.0 \\
\hline Domestic oil & 20.7 & 21.8 & 18.7 & 17.9 & 18.0 \\
\hline Oil shale & 0 & 0.3 & 1.1 & 2.9 & 3.0 \\
\hline Oil imports & 12.8 & 13.3 & 24.3 & 13.0 & 28.2 \\
\hline Domestic gas & 18.6 & 17.6 & 17.8 & 15.4 & 14.2 \\
\hline Gas imports & 1.0 & 1.8 & 3.0 & 1.1 & 3.4 \\
\hline Nuclear & 1.8 & 7.6 & 7.4 & 18.7 & 25.0 \\
\hline Solar (except biomass) & 0 & 0.2 & 0.1 & 1.8 & 1.4 \\
\hline Geotherma1 & 0 & 0.3 & 0.2 & 2.7 & 2.5 \\
\hline Hydropower & 3.0 & 3.1 & 3.1 & 3.6 & 3.6 \\
\hline Biomass & 0 & 0 & 0 & 1.5 & 1.5 \\
\hline National total & 73.2 & 9.4 .2 & 99.6 & 123.5 & 138.8 \\
\hline
\end{tabular}

Source: ERDA 1977.

It is unlikely that the nuclear industry will experience its previous growth rate, leaving coal and various other sources to take up the slack. This means that coal production could increase to a projected value of over 1 billion tons in 1985 from the current level of approximately 640 million tons (U.S. Government 1977). Coal will have to become the nation's chief tool for increasing energy self-reliance. Coal is abundant, the technology to use it is available today, and there is an existing production and distribution base to build on.

What environmental impact might large coal storage piles at combustion and conversion plants have? Sulfur-bearing minerals such as pyrite (iron sulfide), which are commonly associated with coal, will be exposed to air and rainfall where they can be oxidized to form sulfuric acid. Minute concentrations of salts of metals such as zinc, lead, arsenic, copper, or aluminum can be toxic to plants, fish, wildlife, and aquatic insects. In addition, high concentrations of minerals may render water bodies unsuitable as drinking water sources or recreational areas. Related to acid formation are deposits of iron precipitates of ten found in streams that drain sulfur-bearing coal or mineral deposits (Kendrick 1977.). These are but a few of the problems associated with acld wine drainagc and with the storage nt large quantitles of coal. 
Because of the low tolerance levels in plants, animals, and man, the trace elements are of particular concern. Although the relative amounts of these elements per unit of coal is small, the total absolute amount of each available in a large coal storage pile could have important consequences in water, soil, or air quality (Wewerka et al. 1976).

According to the interim primary drinking water standards (U.S. Government 1975), the following are the maximum contaminant levels of inorganic chemicals allowed in public water supplies (see Table 2). Since the literature review shows that coal storage pile leachate contains concentrations of inorganic chemicals in excess of those shown in Table 2, serious water quality degradation could occur if excessive leachate were allowed to enter streams used for public water supplies.

Table 2. Maximum contaminant levels for inorganic chemicals allowed in public water supplies

\begin{tabular}{lc}
\hline Contaminant & Leve1 (mg/liter) \\
\hline Arsenic & 0.05 \\
Barium & 1.0 \\
Cadmium & 0.010 \\
Chromium & 0.05 \\
Cyanide & 0.2 \\
Lead & 0.05 \\
Mercury & 0.002 \\
Nitrate (as N) & 10.0 \\
Seleni.um & 0.01 \\
Silver & 0.05 \\
\hline
\end{tabular}

Source: U.S. Government 1975.

Environmental Protection Agency Steam-Electric Power Plant Effluent Guidelines

Section 301 of Public Law 92-500 required that, by July 1, 1977, power plant discharges meet effluent limitations corresponding to those attainable by application of the "best practicable control technology currently available" (BPCTCA). The act additionally requires that, by 
1983, the treatment or control of pollutant discharge be equivalent to that attainable by the "best available technology economically achievable" (BATEA).

In October 1974, the United States Environmental Protection Agency (EPA) issued guidelines for six wastewater sources in electrical generating plants. These sources include equipment cleaning effluents, bottom ash slurries, fly-ash slurries, cooling tower and boiler blowdown, coal pile and floor drain runoff, and sanitary wastes. The essential components in these waste streams have been found to vary from heavy metals to biochemical oxygen demand and suspended solids (Mace 1977). Table 3 is a summary of these discharge limits for steam-electric plants. It is important to note here that the guidelines stated in Table 3 have been challenged in court and remanded to EPA for further investigation.

As far as coal pile leachate is concerned, the important part of Table 3 is the last line, giving the standards for material storage. runoff. Only two parameters have been included: total suspended solids and $\mathrm{pH}$. In addition, only runoff flow from material-storage plles associated with the reference 10 -year, $24-\mathrm{hr}$ rainfall or greater is exempt from these limitations. This means that coal stored at all coal combustion and conversion sites must meet the limitations set by the EPA guidelines; that is, a TSS of less than $50 \mathrm{mg} / 1 \mathrm{iter}$ and a $\mathrm{pH}$ in the range of $6.0-9.0$. As will be seen from investigations reported in the literature review, this will be impossible without some form of treatment.

Under Section 307 of the Water Pollution Control Act, EPA was also required to publish effluent standards for toxic pollutants. The adequacy of the agency's compliance with this section has been challenged in court, and as a result, a timetable for completion of EPA studies and promulgation of the effluent standards for an agreed list of priority pollutants has been established. This set of standards for toxic pollutants is expected to be completed by March 1979; however, standards for several of these primary pollutants have already been adopted. As soon as this additional list of toxic pollutants has been established and standards set, rnal. pile leachate may be subject to these additional parameters, as well as the TSS and $\mathrm{pH}$ limits. 
Table 3. Discharge limits for steam-electric plants

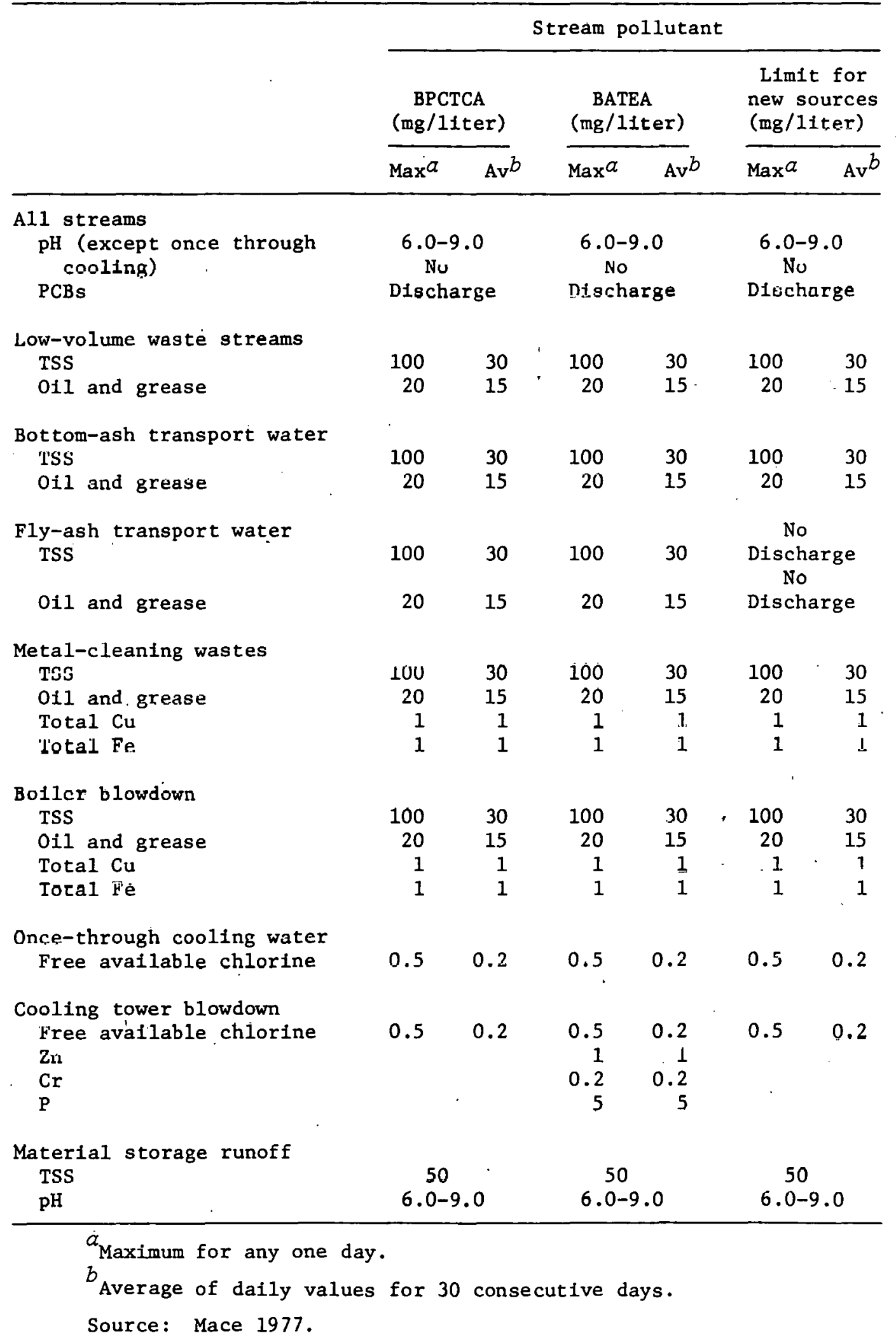


Storage of Coal

Coal storage may be divided into two types according to purpose: live or active storage from which coal feeds directly to firing equipment, and reserve or inactive storage. Usually live storage is under cover and is referred to as in-plant storage; reserve storage is outdoors and is referred to as the stockpile.

The size of the plant usually determines the type and capacity of in-plant and outside storage. These may vary from a small plant that has no storage capacity and receives its coal from a retail coal dealer who stores most of the plant's needs, to a utility that maintains a reserve stockpile in excess of 1 million tons and receives its coal by truck, rail, or barge.

For large coal-fired generating plants, outside storage of coal at or near the site is necessary to assure continuous plant operation. Coal reserves at TVA plants are usually for a period of approximately 90 days. These storage piles are typically 25 to $40 \mathrm{ft}$ high, spread over an area of several acres, and require from 21,000 to $64,000 \mathrm{ft}^{3}$ of storage space for each MW of rated capacity (Nichols 1974).

Significant changes in the physical and chemical properties of coal occur upon exposure to air at atmospheric temperatures. As early as 1879, Fayol (Fayol 1879) recorded the temperatures in various parts of a large pile of coal. The coal was piled at a temperature of $22^{\circ} \mathrm{C}$, and after 90 days a maximum temperature of $150^{\circ} \mathrm{C}$ was recorded at a point $1 \mathrm{ft}$ from the ground in a portion of the pile that was $20 \mathrm{ft}$ deep. In another test he showed that the temperature of a pile of coal that was heating could be decreased by merely excluding air using a tight cover.

The oxidation of pyrite in coal is an exothermic process with heat being generated. By covering the coal storage pile with an airtight seal, Fayol was excluding the necessary oxygen and slowing down the oxidation process. The heat generated in large coal storage piles can lead to spontaneous combustion and is thus an important factor in the design of storage facilities.

Ordinarily these oxidative changes take place slowly, but continuously, from the moment the face of the coal bed is exposed 
to air until the coal is finally utilized, causing a gradual decrease in commercial value. Tests made in various parts of the country on a West Virginia coal indicate losses in heating value of $1.2 \%$ the first year and a maximum of $2.1 \%$ in two years (National Coal Association 1972). Samples of the same coal stored in more moderate climates showed a loss in heating value of about $1.5 \%$ in five years of exposure. Similar tests on Pittsburgh seam coal exposed in open bins for five years showed a loss of less than $1.1 \%$ in heating value. Further experiments on compacted and sealed coal storage piles show reduced loss in heating value and, therefore, reduced loss in investment, which highlight.s the impnrtance of compacting coal during storage.

There is a very limited amount of information available concerning the actual construction of a coal stockpile; however, the following rules are generally followed. Plants having reserve piles larger than 500 tons should always build a compacted coal pile. Compaction seals out air and minimizes spontaneous heating. It also reduces heating-value loss to $1 \%$ or less (National Coal Association 1972).

When possible, piles should be laid out with consideration to ultimate tonnage desired. The top of the pile should be as small in area as possible, yet allow sufficient space to maneuver heavy equipment. Th1s suggestion of a small surface area is not always followed by TVA and other utilities, as witnessed by their large, flat storage piles. Dumping coal on the pile segregates it, creates flues, and promotes heating and fires. The pile should be built in successive layers 1 to 2 ft thick (see Fig. 3). Each layer should be thoroughly compacted by repeatedly running a bulldozer or weighted roller over the coal pile as it is being constructed.

The pile is constructed by sloping the tops of sucressive cod layers toward the sides of the pile. This prevents rain, melting snow, and ice from penetrating the pile. Pile sides should not be too steep; an angle of $30^{\circ}$ to the horizontal is a good slope to maintain. Steep side slopes can cause segregation and erosion from wind and rain.

The top of the pile is crowned slightly, or allowed to slope in one direction. Saucer-shaped tops create a problem of standing water, which wets the coal so that it tends to clog chutes and conveyors. 


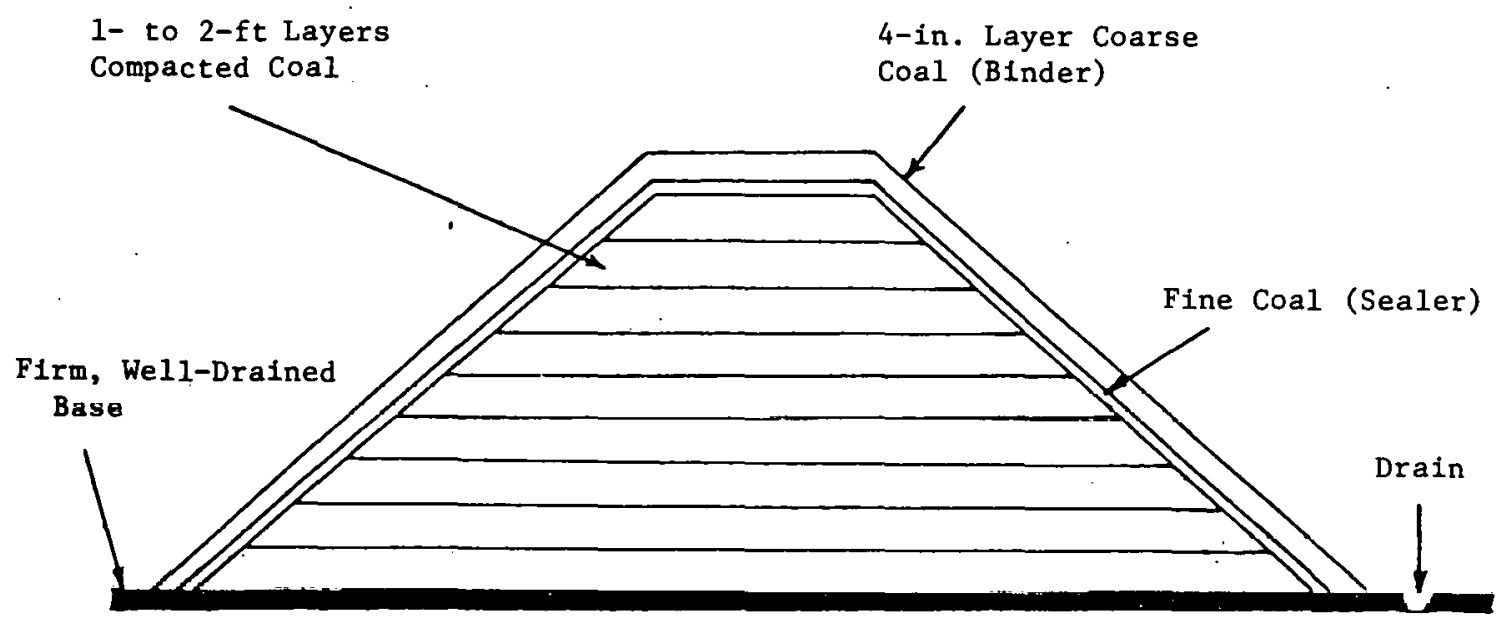

Fig. 3. Cross section of a compacted coal pile.

It is recommended that, insofar as possible, only one type of coal be placed in the stockpile. For large compacted reserve storage piles, the coal should be of varying sizes not exceeding 2 in. Size breakdown should be such as to minimize the void volume in the coal as it is compacted. All of these techniques should be employed, where possible, to reduce the weathering of coal and slow down the natural oxidation process. 


\section{LITERATURE REVIEW - COAL PILE LEACHATE}

The following section of this report deals with the literature that has been published concerning coal storage pile leachate. The majority of the articles were published between 1970-1977, since it was during this time period that increased interest was focused on leachate from large coal storage piles. Related subjects, including runoff from coal refuse piles, and the carrier water used in coal slurry pipelines are also briefly discussed, however, the major emphasis is on coal storage piles and the quality of their leachate. Every attempt has been made to cover all information sources, however since some document titles and key-word descriptors do not mention coal storage, some information may have been overlooked.

Current research being supported by the Environmental Protection Agency concerning problems associated with coal leachate was discussed at the National Conference on Health, Environmental Effects, and Control Technology of Energy Use (EPA 1976). Two projects were outlined; however, results have not yet been made available for analysis.

The first project is concerned with particulate and leachate transport from fine particulate coal while in storage at the DuluthSuperior port, and with the effects of these materials on aquatic biota. 'The chemistry and biology departments at the University of Wisconsin, Superior, and the University of Minnesota, Duluth, are cooperating to characterize inorganic and organic leachates from coal and to characterize the biological condition of the bay.

A second project is now under way at the Los Alamos Scientific Laboratory with the purpose of identifying the inorganic and organic constituents released during aqueous leaching of stored coals under conditions typically encountered in the environment. Two different coal samples are to be used for this study. One of these samples is a highsulfur coal from the Illinois Basin. The second is a low-sulfur eastern coal from the Appalachian Province. Both are from regions of high coal production where more than $127 \mathrm{~cm}$ of precipitation occurs annually. Work will center on the study of the unwashed coals, which represent 
about one-half of the coals currently consumed and should produce greater environmental releases than washed coals. Results from these laboratory leaching studies should be published in the near future.

Roffman and Roffman (Roffman et al. 1975) have reported that the quality of surface and groundwater bodies can be dangerously degraded by coal pile leachate and acid mine drainage. The acidic drainage results when sulfuric acid forms from the oxidation of pyrite and marcasite coal inclusions in the presence of water, oxygen, and bacteria. Such waters have an acid $\mathrm{pH}$ and contain high concentrations of iron, calcium, magnesium, and sulfate ions as well as aluminum, sodium, manganese, and many trace elements. The mining of low-sulfur western coals usually does not result in acid formation because of the low concentrations of iron sulfide, the relatively dry climatological conditions, and the buffering capacity of the soil. This investigation also points out the importance of the layer of soil beneath a coal storage pile, and indicates that this natural buffering capacity must be taken into consideration when coal leachate samples are taken at a distance from the storage pile after it has had a chance to interact with the soil.

In the draft environmental impact statement for the Coal Research, Development, and Demonstration Program, the Energy Research and Development Administration (ERDA) addressed the probable water quality problems associated with increased utilization of coal in the United Stateg (ERDA 1977). They state the potential concerns as being: (1) the presence of potentially toxic and carcinogenic organic compounds in coal residues and products, and (2) the potential presence of trace metal pollutants in the products and by-products. They conclude by stating that little is known about these subjects, and consequently further research and development are needed.

One of the most of ten quoted tables concerning the quality of coal pile leachate is presented in the development document for proposed effluent limitations guidelines and new source performance standards for the steam-electric power generating industry (Nichols 1974). In this particular document the Environmental Protection Agency evaluated the 
coal pile leachate at several operating power plants in the United States. The results are summarized in Table 4.

Table 4. EPA survey results - coal pile leachate quality

\begin{tabular}{lcc} 
& Mean (mg/11ter) & Range (mg/1iter) \\
Parameter & $\mathrm{pH}=2.7$ & $\mathrm{pH}=2.1-3.0$ \\
\hline Iron & 19,540 & $0.17-93,000$ \\
Sulfate & 9,006 & $525-21,920$ \\
Zinc & 3.64 & $1.6-23$ \\
Coppor & 2.10 & $1.6-3.4$ \\
Chromium & 3.27 & $0-15.7$ \\
TDS & 16,440 & $720-44,050$ \\
\hline
\end{tabular}

Source: Nichols 1974.

This table gives a general idea of the order of magnitude of certain parameters, but says nothing concerning the time period over which the samples were taken or what type of coal was being stored at each of the power plants. This type of data is presented frequently. in the literature, but is of limited value for comparison purposes, unless it Is accompanied by a more detailed analysis of coal type, sampling procedure, and previous storage periods.

A recent coal pile leachate study has been conducted on the coal stockpile at Cornell University (Anderson and Youngstrom 1976). In this study, coal pile leachate quality. was monitored concurrently with coal pile leachate flow by field measurements and collection of samples for subsequent laboratory analysis. The parameters monitored included $\mathrm{pH}$, ferrous and total iron, acidity, total dissolved solids, copper, manganese, chromium, and zinc. In order to adequately characterize the variablltty of coal pile leachate quality during a rainfall, the following sampling schedule was employed: (1) commencing at the beginning of every rainfall and continuing until $2 \mathrm{hr}$ after the rainfall stopped, samples were collected every $1 / 2 \mathrm{hr}$; (2) commencing $2 \mathrm{hr}$ after each rainfall had stopped and continuing until the flow of leachate stopped, samples were collected every $4 \mathrm{hr}$. This sampling schedule was used on the three rainfall events which occurred on May 4 (46 mm), May 12 (13 mm), 
and May $15(9.1 \mathrm{~mm})$, 1975. A summary of the coal pile leachate quality is shown in Table 5 .

Table 5. Summary of leachate quality

\begin{tabular}{lcc}
\hline \multicolumn{1}{c}{ Parameter } & Mean value (mg/1iter) & $\begin{array}{c}\text { Range (mg/1iter) } \\
\mathrm{pH}=2.2-5.8\end{array}$ \\
\hline Acidity & 2,562 & $375-8250$ \\
Total iron & 1,144 & $10-5250$ \\
Ferrous iron & 490 & $139-850$ \\
Copper & 1.69 & $0.1-6.1$ \\
Manganese & 17.1 & $4.5-72.0$ \\
Chromium & 2.6 & $0.1-7.5$ \\
Zinc & 5.9 & $2.4-26.0$ \\
Total dissolved solids & 11,745 & $9332-14,948$ \\
\hline
\end{tabular}

Source: Anderson and Youngstrom 1976.

Anderson and Youngstrom conclude that during periods of no preclpitation, retained moisture within the coal pile dissolves minerals that will be flushed from the pile by precipitation. If there is sufficient precipitation, most of the dissolved minerals are flushed from the pile, and following the first flush, only minor concentrations of minerals are carried from the pile in continuing coal pile leachate flows. Provided the size and configuration of the coal pile is not changed, the amount of contaminants which can be generated and flushed from a coal pile is dependent upon the reaction time allowed to occur within the coal pile before the contaminants are flushed by precipitation. The time required to complete the flushing of contaminants from the coal pile is dependent upon the volume of water applied to the pile and the duration of the application.

Before flushing was complete, it was noted that the concentration of contaminants was inversely proportional to the coal pile leachate flow; and after the flushing was complete, there was relatively little change in contaminant concentration with change in flow rate.

These experiments carried out on the Cornell University campus are sufficient to characterize coal pile leachate during the rainfalls which 
occurred during the month of May 1975. However, no attempt was made to characterize leachate from coal storage piles over a long period of time and under varying weather conditions.

In a discussion of this paper by McFall (McFall 1977), two other major weaknesses were found in the article: (1) lack of snow leachate data, and (2) chemical analysis of the coal. McFall states that coal piles which have had snow resting on them will create leachate with different characteristics from those subjected only to rainfall. Because the chemical constituents of coal vary considerably, for comparison purposes it is essential to report the chemical constituents of the subject coal. This is something the authors did not do.

In 1975 , Metry presented information on the treatability and treatment of leachate and contaminated runoff waters from a coal transshipment facility (Metry 1975). He stated that a coal stockpile will produce two types of contaminated waters. First, runoff occurs, causing particulates to wash off the surface; second, rainwater slowly percolates through the stockpile, taking some chemicals into solution in addition to concentrating pile-bound particulates.

In Metry's investigation, the quality of leachate and contaminated runoff from a coal handling facility was determined by laboratory simulation using a western coal. Distilled water was allowed to percolate through a 6-ft-long, 2-in.-diam glass column filled with coal, and the leachate was collected and analyzed. Table 6 is an analytical summary of the results.

In conclusion, Metry states that the results from laboratory experimentation for the tested western coal suggested that the acidproducing capacity of this coal is less than the inherent alkalinity of the coal under all conditions encountered in a stockpile. This balance between acid-producing capacity and inherent alkalinity seems to be the most important factor in the potential for producing acidic leachate. Heavy metals and other trace elements in leachate are direct functions of the acidity and, thus, the pyritic sulfur content in coal. Leachate 
Table 6. Summary of leachate under wet aeroblc, intermediate aerobic, and anaerobic conditions

\begin{tabular}{lccc}
\hline & $\begin{array}{c}\text { Wet aerobic } \\
\text { conditions } \\
\text { (mg/liter) } \\
\text { pH } 7.4\end{array}$ & $\begin{array}{c}\text { Intermediate } \\
\text { conditions } \\
\text { (mg/liter) } \\
\text { PH } 7.2\end{array}$ & $\begin{array}{c}\text { Anaerobic } \\
\text { conditions } \\
\text { (mg/1iter) } \\
\text { pH } 8.0\end{array}$ \\
\hline TDS & 490 & 1720 & 592 \\
Alkalinity & 54 & 37.5 & 124 \\
$\mathrm{Fe}$ & 0.65 & 12 & 0.85 \\
$\mathrm{~V}$ & $<2$ & $<2$ & $<2$ \\
$\mathrm{~Pb}$ & $<0.1$ & $<0.1$ & $<0.1$ \\
$\mathrm{Zn}$ & 0.15 & 0.2 & 0.23 \\
$\mathrm{Cd}$ & $<0.05$ & $<0.05$ & $<0.05$ \\
$\mathrm{Cr}$ & $<0.05$ & $<0.05$ & $<0.05$ \\
$\mathrm{Mn}$ & $<0.05$ & 0.08 & 0.05 \\
$\mathrm{Sr}$ & 0.2 & 0.33 & 0.1 \\
$\mathrm{Cu}$ & 0.12 & 0.15 & $<0.05$ \\
$\mathrm{Li}$ & $<0.05$ & $<0.05$ & 0.05 \\
\hline
\end{tabular}

Source: Metry 1975.

from facilities handling low-sulfur western coals should contain lower heavy metal, and other trace element concentrations than leachate from facilities handling high-sulfur eastern coals.

The difference between western and eastern coal is mainly in the sulfur content of each. Among United States reserves, western coals are generally of lower rank and sulfur content, whereas interior province and most Appalachian coals, which were formed under the influence of high sulfate ion concentrations in saline waters, contain greater amounts of sulfur. Additional differences occur in the trace-element content as shown in Tables 7 and 8 .

Due to the many coal-fired power plants in the Tennessee Valley, the Tennessee Valley Authority (TVA) is becoming increasingly concerned with the quality and quantity of coal pile leachate. Cox, Chu, and Ruane have been conducting research concerning the quality and treatment of coal pile runoff at two TVA coal-fired steam plants (Cox, Chu, Ruane 1977). In their investigation they analyzed coal pile leachate composite samples from storm events for $\mathrm{pH}$, acidity, dissolved solids, suspended solids, sulfate, iron, and manganese. The means and ranges of the project data are presented in Table 9. 
Table 7. Trace-element content of American coals (ppm in coal)

\begin{tabular}{|c|c|c|c|c|}
\hline \multirow[b]{2}{*}{ Element } & \multicolumn{4}{|c|}{ Region } \\
\hline & $\begin{array}{l}\text { Northern } \\
\text { Great Plains }\end{array}$ & $\begin{array}{l}\text { Western } \\
\text { Interior }\end{array}$ & $\begin{array}{l}\text { Eastern } \\
\text { Interior }\end{array}$ & Appalachian \\
\hline Bery11ium & 1.5 & 1.1 & 2.5 & 2.5 \\
\hline Boron & 116 & 33 & 96 & 25 \\
\hline Titanium & 591 & 250 & 450 & 340 \\
\hline Vanadium & 16 & 18 & 35 & 21 \\
\hline Chromiium & 7 & 13 & 30 & 13 \\
\hline Cobalt & 2.7 & 4.6 & 3.8 & 5.1 \\
\hline Ninckn! & 7.2 & 14 & 15 & 14 \\
\hline Coppei & 15 & 11 & 11 & 15 \\
\hline Zinc & 59 & 108 & 44 & 7.6 \\
\hline Gallium & 5.5 & 2.0 & 4.1 & 4.9 \\
\hline Germanium & 1.6 & 5.9 & 13 & 5.8 \\
\hline Molybdenum & 1.7 & 3.1 & 4.3 & 3.5 \\
\hline Tin & 0.9 & 1.3 & 1.5 & 0.4 \\
\hline Yttrium & 13 & 7.4 & 7.7 & 14 \\
\hline Lanthanum & 9.5 & 6.5 & 5.1 & 9.4 \\
\hline
\end{tabular}

Source: Zubovic 1975.

'lable 8 . Distribution of environmentally hazardnus trace elements ( $\mathrm{ppm}$ in coa1)

\begin{tabular}{lcccc}
\hline & \multicolumn{4}{c}{ Region } \\
\cline { 2 - 5 } Element & $\begin{array}{c}\text { Powder River } \\
\text { Basin }\end{array}$ & $\begin{array}{c}\text { Western } \\
\text { Interior }\end{array}$ & $\begin{array}{l}\text { Eastern } \\
\text { Tnterinr }\end{array}$ & Appalachinn \\
\hline Antimony & 0.67 & 3.5 & 1.3 & 1.2 \\
Arsenic & 3 & 16 & 14 & 18 \\
Beryllium & 0.7 & 2 & 1.8 & 2.0 \\
Cadmium & 2.1 & 20 & 2.3 & 0.2 \\
Mercury & 0.1 & 0.13 & 0.19 & 0.16 \\
Lead & 7.2 & 5.7 & 34 & 12 \\
Selenium & 0.73 & & 2.5 & 5.1 \\
Zinc & 33 & & 250 & 13 \\
\hline
\end{tabular}

Source: Zubovic 1975. 
Table 9. Coal pile leachate data from TVA plants $J$ and $E$

\begin{tabular}{|c|c|c|c|c|c|c|c|}
\hline & $\mathrm{pH}$ & $\begin{array}{c}\text { Acidity } \\
\left.\text { (mg/liter } \mathrm{CaCO}_{3}\right)\end{array}$ & $\begin{array}{l}\text { Sulfate } \\
\text { (mg/liter) }\end{array}$ & $\begin{array}{l}\text { Dissolved } \\
\text { solids } \\
\text { (mg/liter) }\end{array}$ & $\begin{array}{l}\text { Suspended } \\
\text { solids } \\
\text { (mg/liter) }\end{array}$ & $\begin{array}{c}\text { Iron } \\
\text { (mg/1iter) }\end{array}$ & $\begin{array}{l}\text { Manganese } \\
\text { (mg/liter) }\end{array}$ \\
\hline \multicolumn{8}{|c|}{ Plant I } \\
\hline $\begin{array}{l}\text { Range } \\
\text { Mean }\end{array}$ & $\begin{array}{l}2.3-3.1 \\
2.79\end{array}$ & $\begin{array}{c}300-7100 \\
3400\end{array}$ & $\begin{array}{l}1800-9600 \\
5160\end{array}$ & $\begin{array}{c}2500-16000 \\
7900\end{array}$ & $\begin{array}{l}8.0-2300 \\
470\end{array}$ & $\begin{array}{l}240-1800 \\
940\end{array}$ & $\begin{array}{c}8.9-45 \\
28.7\end{array}$ \\
\hline \multicolumn{8}{|c|}{ Plant E } \\
\hline $\begin{array}{l}\text { Range } \\
\text { Mean }\end{array}$ & $\begin{array}{l}2.5-3.1 \\
2.67\end{array}$ & $\begin{array}{c}860-2100 \\
1360\end{array}$ & $\begin{array}{l}1900-4000 \\
2780\end{array}$ & $\begin{array}{c}2900-5000 \\
3600\end{array}$ & $\begin{array}{l}38-270 \\
190\end{array}$ & $\begin{array}{c}280-480 \\
380\end{array}$ & $\begin{array}{c}2.4-10.0 \\
4.13\end{array}$ \\
\hline \multicolumn{8}{|c|}{ Plant E Storm Feb. 24, 1977} \\
\hline $\begin{array}{l}\text { Range } \\
\text { Mean }\end{array}$ & $\begin{array}{c}2.5-2.7 \\
2.63\end{array}$ & $\begin{array}{c}300-1400 \\
710\end{array}$ & $\begin{array}{l}870-5500 \\
2300\end{array}$ & $\begin{array}{c}1200-7500 \\
2700\end{array}$ & $\begin{array}{l}69-2500 \\
650\end{array}$ & $\begin{array}{l}62-380 \\
150\end{array}$ & $\begin{array}{c}0.88-5.4 \\
2.3\end{array}$ \\
\hline
\end{tabular}

Source: Cox, Chu, Ruane 1977. 
Information on trace-element concentrations from the same two plants is presented in Table 10.

In a summary of their work they have concluded that the drainage from the two plants, $J$ and $E$, is a highly acidic waste stream containing high concentrations of a wide variety of inorganic constituents. Further, the acidity of this waste stream may not be governed by the total sulfur content of the coal, since the coal supplied to plant $\mathrm{E}$ was high in sulfur $(>3 \%)$, and the coal supplied to plant $J$ was moderate in sulfur content ( 1 to $3 \%$ ), but the measured $\mathrm{pH}$ values were quite similar. These results suggest that some other tactor, in addition to total sultur content, is possibly responsible for coal pile leachate $\mathrm{pH}$; however, more research needs to be conducted along these lines. It is more likely that samples were not taken over a long enough period of time to realize the full acid-forming potential of the high-sulfur coal.

Earlier work at TVA has been conducted by Chu, Ruane, and Steiner, in which the coal pile leachate from two TVA power plants has been analyzed (Chu, Ruane, Steiner 1976). The results are presented in Table 11, which is very informative concerning the quality of the leachate from these two plants, but again nothing is mentioned regarding the type of coal stored or the conditions under which samples were taken. This is typical of the information that has been found concerning coal pile leachate and limits the use of this data.

Rice and Strauss, in work aimed at water pollution control in steam plants, have presented information on coal pile leachate from several power plants (Rice and Strauss 1972). They state that the Federal Water Pollution Control Act Amendment of 1972 has brought about some fundamental changes in the manner in which power generation facilities discharge chemical wastes, and that coal pile runoff is another stream which needs to be contended with. The amount of rainfall that runs off or percolates through coal storage piles is a function of the area of the pile and the rainfa11. These two factors, plus the composition of the coal, affect the concentrations in the pile runoff water.

The reaction of coal minerals with the rainwater and the oxygen in the air is similar to that which takes place in coal mines, causing 
Table 10. Trace-metal data from TVA plants $\mathrm{J}$ and $\mathrm{E}$ (mg/1iter)

\begin{tabular}{|c|c|c|c|}
\hline Parameter & & P1ant $\mathrm{J}$ & Plant $\mathrm{E}$ \\
\hline Copper & $\begin{array}{l}\text { Range } \\
\text { Mean }\end{array}$ & $\begin{array}{c}0.43-1.4 \\
0.86\end{array}$ & $\begin{array}{c}0.01-0.46 \\
0.23\end{array}$ \\
\hline Zinc & $\begin{array}{l}\text { Range } \\
\text { Mean }\end{array}$ & $\begin{array}{c}2.3-16 \\
6.68\end{array}$ & $\begin{array}{c}1.1-3.7 \\
2.18\end{array}$ \\
\hline Cadmium & $\begin{array}{l}\text { Range } \\
\text { Mean }\end{array}$ & $\begin{array}{c}<0.001-<0.001 \\
<0.001\end{array}$ & $\begin{array}{c}<0.001-0.003 \\
0.002\end{array}$ \\
\hline Aluminum & $\begin{array}{l}\text { Range } \\
\text { Mean }\end{array}$ & $\begin{array}{l}66.0-440 \\
260\end{array}$ & $\begin{array}{c}22.0-60.0 \\
43.3\end{array}$ \\
\hline Nickel & $\begin{array}{l}\text { Range } \\
\text { Mean }\end{array}$ & $\begin{array}{c}0.74-4.5 \\
2.59\end{array}$ & $\begin{array}{c}0.24-0.46 \\
0.33\end{array}$ \\
\hline Chromium & $\begin{array}{l}\text { Range } \\
\text { Mean }\end{array}$ & $\begin{array}{c}<0.005-0.011 \\
0.007\end{array}$ & $\begin{array}{c}<0.005-0.011 \\
0.007\end{array}$ \\
\hline Mercury & $\begin{array}{l}\text { Range } \\
\text { Mean }\end{array}$ & $\begin{array}{c}<0.0002-0.0025 \\
0.0004\end{array}$ & $\begin{array}{c}0.003-0.007 \\
0.004\end{array}$ \\
\hline Arsenic & $\begin{array}{l}\text { Range } \\
\text { Mean }\end{array}$ & $\begin{array}{c}0.005-0.6 \\
0.17\end{array}$ & $\begin{array}{c}0.006-0.046 \\
0.02\end{array}$ \\
\hline Selenium & $\begin{array}{l}\text { Range } \\
\text { Mean }\end{array}$ & $\begin{array}{c}<0.001-0.03 \\
0.006\end{array}$ & $\begin{array}{c}<0.001-0.001 \\
0.001\end{array}$ \\
\hline Bery1lium & $\begin{array}{l}\text { Range } \\
\text { Mean }\end{array}$ & $\begin{array}{c}0.03-0.07 \\
0.044\end{array}$ & $\begin{array}{c}<0.01-0.03 \\
0.014\end{array}$ \\
\hline
\end{tabular}

Source: Cox, Chu, Ruane 1977. 
Table 11. Characteristics of coal pile drainage (pH 2.9)

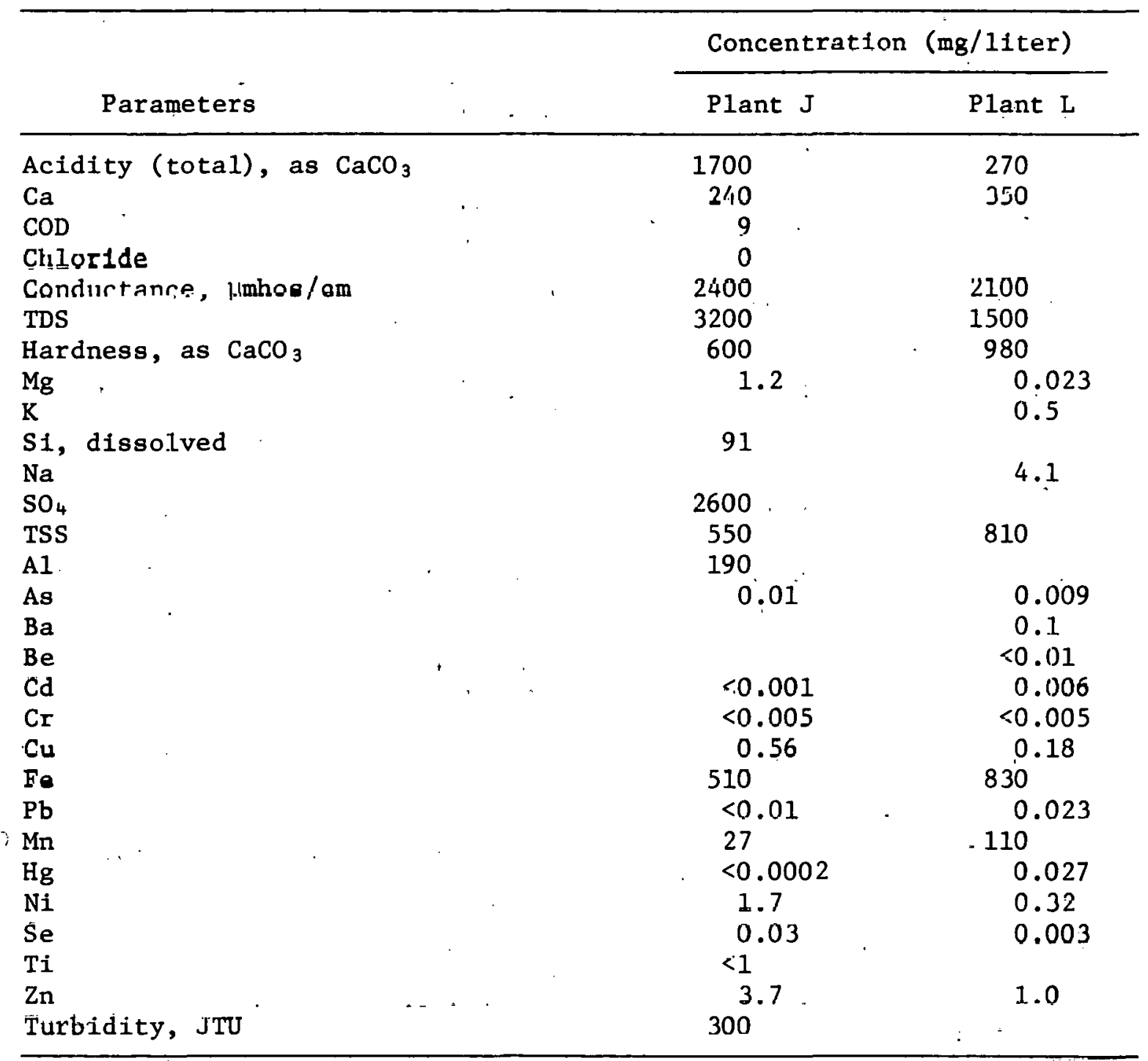

Source: Chu, Ruane, Steiner 1976. 
contaminated mine drainage. Although the exact reaction processes are still not fully understood, the formation of acid can be illustrated by the following. equations:

$$
\begin{aligned}
& 2 \mathrm{FeS}_{2}+7 \mathrm{O}_{2}+2 \mathrm{H}_{2} \mathrm{O} \rightarrow 2 \mathrm{FeSO}_{4}+2 \mathrm{H}_{2} \mathrm{SO}_{4} \\
& 4 \mathrm{FeSO}_{4}+2 \mathrm{H}_{2} \mathrm{SO}_{4}+\mathrm{O}_{2} \rightarrow 2 \mathrm{Fe}_{2}\left(\mathrm{SO}_{4}\right)_{3}+2 \mathrm{H}_{2} \mathrm{O}
\end{aligned}
$$

Depending on physical and chemical conditions, the reaction may then proceed to form ferric hydroxide or basic ferric sulfate (Braley 1951, Parsons 1968):

$$
\begin{aligned}
& \mathrm{Fe}_{2}\left(\mathrm{SO}_{4}\right)_{3}+6 \mathrm{H}_{2} \mathrm{O} \rightarrow 2 \mathrm{Fe}(\mathrm{OH})_{3}+3 \mathrm{H}_{2} \mathrm{SO}_{4} \\
& \mathrm{Fe}_{2}\left(\mathrm{SO}_{4}\right)_{3}+2 \mathrm{H}_{2} \mathrm{O} \rightarrow 2 \mathrm{Fe}(\mathrm{OH})\left(\mathrm{SO}_{4}\right)+\mathrm{H}_{2} \mathrm{SO}_{4}
\end{aligned}
$$

Other constituents found in coal pile drainage are produced by secondary reactions of sulfuric acid with minerals and organic compounds present in the coal. Such secondary reactions are thought to be dependent upon type of coal and chemical conditions of the pile (Temple and.Colmer 1951).

The pyritic content of the coal seems particularly important in determining the amount of metal sulfates and sulfuric acid produced, since it is the reaction of the iron sulfides with oxygen that produces the sulfate and the acid. The latter dissolves many other complex sulfides and sulfosalts, releasing some or all of the following metals: aluminum, zinc, copper, cadmium, baryllium, nickel, chromium, vanadium, silver, and lead. Table 12 is a summary of the quality of coal pile runoff at selected plants reported by Rice and Strauss.

This table is quite informative and demonstrates the wide variability in parameters that can occur in coal pile leachate. It is, however, difficult to draw any firm conclusions concerning the concentrations of various elements in coal pile runoff, because these reported values are only for grab samples at a particular site and represent coa $\perp$ 
Table 12. Coal pile runoff analysis at selected plants (mg/liter)

\begin{tabular}{|c|c|c|c|c|c|c|c|}
\hline & $\begin{array}{c}\text { Plant } \\
\text { A }\end{array}$ & $\underset{B}{P l \text { ant }}$ & $\begin{array}{c}\mathrm{Pl} \text { ant } \\
\mathrm{C}\end{array}$ & $\underset{\mathrm{D}}{\mathrm{Plant}}$ & $\begin{array}{c}\text { Plant } \\
E\end{array}$ & $\begin{array}{c}\mathrm{Plant} \\
\mathrm{F}\end{array}$ & $\begin{array}{c}\text { Plant } \\
G\end{array}$ \\
\hline Alkalinity & 6 & 0 & & & 14.32 & 36.41 & \\
\hline Total solids & 1330 & 9999 & & & & & 6000 \\
\hline TDS & 720 & 7743 & & 28,970 & & & 5800 \\
\hline TSS & 610 & 22 & & 100 & & & 200 \\
\hline Ammonia & 0 & 1.77 & & & & & 1.35 \\
\hline Nitrate & 0.3 & 1.9 & & & & & 1.8 \\
\hline Phosphorus & & 1.2 & & & & & \\
\hline Turbidity & 505 & & & & 2.77 & 6.13 & \\
\hline Acidity & & & & 21,700 & 10.25 & 8.84 & \\
\hline Total hardness & 130 & 1109 & & & & & 1851 \\
\hline Sulfate & 525 & 5231 & .6837 & 19,000 & & & 861 \\
\hline Chloride & 3.6 & 481 & & & & & \\
\hline Aluminum. & & & & 1200 & & & \\
\hline Chromium & 0 & 0.37 & & 15.7 & & & 0.05 \\
\hline Copper & 1.6 & & & 1.8 & & & \\
\hline Iron & 0.168 & & 0.368 & 4700 & 1.05 & 0.9 & 0.06 \\
\hline Magnesium & 0 & 89 & & & & & 174 \\
\hline Zinc & 1.6 & 2.43 & & 12.5 & & & 0.006 \\
\hline Sodium & 1260 & 160 & & & & & \\
\hline $\mathrm{pH}$ & 2.8 & 3 & 2.7 & 2.1 & 6.6 & 6.6 & 4.4 \\
\hline
\end{tabular}

Source: Rice and Strauss 1972.

that has been weathering for varying lengths of time: In addition, no information has been presented about the type of coal being stored, or how many and under what conditions the samples were taken. No decisions about coal pile leachate quality should be based on Table 12 .

During the past several years the Ontario Hydro Company has become increasingly concerned about the control of air and water contaminants from their large coal storage piles. Featherby and Dodd have been studying this problem (Featherby and Lodd 1977).

Due to the winter freezing of the Great Lakes, Ontario Hydro is forced to purchase enough coal to satisfy winter peak power demands during the summer months, usually some time in April through to mid-December. 'l'he results of this coal transportation problem are that each plant must receive its year's supply of coal during a 30- to 36-week shipping season and by mid-December must have built a stockpile able to sustain the stations at high load for the next 16 to 18 weeks with a contingency cushion equivalent to 4 to 6 weeks full-load consumption in 
case there are delays in ice breakup or other problems in the spring of the year.

One of these large storage piles was the subject of a coal pile leachate study in 1975. From May to November, drainage water samples were collected and analyzed for chemical composition. The results are shown in Table 13.

Featherby and Dodd noted that a marked decrease in the acidity, iron, and sulfate content of the leachate was observed in the samples collected during colder weather in October and November; however, acidic leachate was found even during winter whenever flow was observed. Also, it was observed that dissolved solids, iron, and sulfate could be correlated with total acidity.

Concentrations of trace elements were also of concern, and Table 14 shows the results of samples taken for their analysis.

Three rainstorm events were also investigated for quantity and quality of leachate. It was observed that except for heavy rainfall, little change was noted in leachate composition. The most significant feature of heavy rainfall was the reduced level of contaminants during the latter stage of the runoff. The effluent quality generally returned to normal levels within $24 \mathrm{hr}$ of the cessation of rainfall.

Featherby and Dodd attempted to correlate rainfa11 and discharge volumes so that predictions of the amount of runoff could be made for typical meteorological conditions. It was generally true that the fraction of rainfall appearing as runoff increased with the total volume of rainfall, and that short intense storms returned less than less intense storms of equivalent total volume, but a more rigorous statement could not be made without considerably more accumulated data.

A problem very similar to coal pile leachate, but one which has received much more attention in the literature, is that of acid mine drainage and its effects on receiving water quality. Not only does the acid directly impact stream biota, corrode metal structures, and destroy concrete, but as a result of. the low $\mathrm{pH}$, other ions such as heavy metals become solubilized and are carried into water courses. These ions are of ten toxic to aquatic life and render the water unsuitable for domestic and industrial use. 
Table 13. Average analysis of base flow coal pile drainage (mg/1iter)

\begin{tabular}{lccc}
\hline \multicolumn{1}{c}{ Parameter } & Average & High & Low \\
\hline pH (units) & 2.7 & 2.9 & 2.4 \\
Acidity (as $\mathrm{CaCO}_{3}$ ) & 1500 & 2850 & 300 \\
Dissolved solids & 6500 & 11,600 & 4600 \\
Sulfate & 4100 & 6900 & 1100 \\
Iron & 420 & 1000 & 150 \\
Calcium & 400 & 540 & 200 \\
Sodium & 300 & 440 & 140 \\
Magnesium & 170 & 440 & 9 \\
Chlurlde & 160 & 190 & 111 \\
Aluminum & 52 & 75 & 48 \\
Silica & 22 & 64 & 12 \\
Manganese & 7 & 12 & 3.4 \\
Potassium & 5 & 10 & 1.6 \\
\hline
\end{tabular}

Source: Featherby and Dodd 1977.

Table 14. Maximum and minimum concentrations of trace constituents of coal pile drainage (mg/liter)

\begin{tabular}{lccc}
\hline Parameter & Maximum & Minimum & No. of analysis \\
\hline $\mathrm{Ni}$ & 2.8 & 0.2 & 8 \\
$\mathrm{Cu}$ & 1.6 & $<0.2$ & 7 \\
$\mathrm{Co}$ & 0.4 & 0.09 & 12 \\
$\mathrm{Cr}$ & 0.4 & 0.02 & 6 \\
$\mathrm{Zn}$ & 0.3 & 0.2 & 5 \\
$\mathrm{Ph}$ & 0.2 & 0.02 & 3 \\
$\mathrm{Am}$ & 0.1 & $<0.005$ & 5 \\
$\mathrm{Se}$ & 0.02 & $<0.005$ & 5 \\
$\mathrm{Sb}$ & 0.01 & & 5. \\
$\mathrm{Cd}$ & 0.002 & & 8 \\
$\mathrm{~V}$ & $<1$ & & 4 \\
$\mathrm{Mo}$ & $<1$ & $<0.001$ & 2 \\
$\mathrm{Be}$ & $<1$ & 37 & 4 \\
$\mathrm{Phenols}$ & 0.012 & & 11 \\
$\mathrm{COD}$ & 161 & & 5 \\
\hline
\end{tabular}

Source: Featherby and Dodd 1977. 
It has been estimated that in excess of 10,000 miles of streams have been degraded by acid mine drainage. The amount, rate of acid formation, and the quality of water discharged are a function of the amount and type of pyrite in the overburden rock and coal, time of exposure, characteristics of the overburden, and amount of available water (Hill and Bates 1977).

It is not the intention of this investigation to present a detalled literature review of the generation and treatment of acid mine drainage, but rather to point out the similarities between coal pile leachate and acid mine drainage in an attempt to further define the characteristics and effects of coal pile leachate on existing water quality.

Good, Ricca, and Shumate (Good et al. 1970) define the three most significant sources of acid mine drainage as underground mines, strip mines, and refuse piles; the last normally being associated with coal cleaning plants. The important similarity between refuse piles and coal storage piles is that both represent a source of pyrite, and other sulfur compounds, directly exposed to both oxygen and moisture at the pile surface. As a result, drainage from such piles is extremely high in mineral acidity, sulfates, and iron, all of which have a degrading effect on water quality.

The refuse pile under investigation by Good et al. was regarded as being reactive only at the surface exposed to the atmosphere, the zone of reaction extending only a few inches into the pile. This may or may not be true in the case of a coal storage pile, and would be dependent upon such factors as size of coal, degree of compaction, and the presence of surface coverings. Between rains it was found that the pyrite oxidation reaction proceeded at a more or less uniform rate, with the acid products accumulating in the outer reactive mantle. When a storm occurred, it was estimated that about $70 \%$ of the acid salts appear in the runoff, and the remainder are carried into the interior of the pile, eventually reappearing as seepage around the pile perimeter. This flushing of the coal pile during a rainstorm was also noted by Anderson and Youngstrom (Anderson and Youngstrom 1976). 
Martin has published data concerning the quality of effluents from coal refuse piles located in five states (Martin 1974). In order to compare the quality of drainage from refuse piles sampled by Martin with that from coal storage piles, Table 15 has been constructed. This table gives average values of the analysis of effluents from each of the five states. It is important to keep in mind that these leachate samples were taken from mining refuse piles and not laboratory leaching experiments conducted on coal samples.

Martin concludes his discussion of coal refuse piles by stating that the silt, heavy metals, and acid constitute the major water pollution hazards. The amount of these pollutants can be related to the compaction of the refuse, angle of side slopes, soil cover or surface water control, and the basic geologic formation of the coal that has been mined.

Table 15. Analysis of effluents from refuse piles (mg/liter)

\begin{tabular}{|c|c|c|c|c|c|}
\hline Parameter & Pennsylvania & $\begin{array}{l}\text { West } \\
\text { Virginia }\end{array}$ & Kentucky & Indiana & I11inois \\
\hline $\mathrm{pH}$ & 4.1 & 3.9 & 4.1 & 3.25 & 3.0 \\
\hline $\begin{array}{l}\text { Conductivity } \\
(\mu \mathrm{mhos} / \mathrm{cm})\end{array}$ & 4694 & 5793 & 2784 & $51 \cdot 16$ & \\
\hline Total acidity & $715 \%$ & 1656 & 1929 & 6374 & 6723 \\
\hline Alkalinity & 84 & & 135 & 195 & \\
\hline $\mathrm{SO}_{4}$ & 8648 & 4260 & 3180 & 8110 & 2707 \\
\hline $\mathrm{Na}$ & 29.7 & 330 & 117 & 84 & \\
\hline $\mathrm{Mg}$ & 73 & 271 & 90.4 & 152 & \\
\hline A1 & 285 & 42.9 & 153 & 91.5 & \\
\hline $\mathrm{K}$ & 4.0 & 15,2 & 14.9 & 3.5 & \\
\hline $\mathrm{Ca}$ & 112 & 252 & 137 & 250 & \\
\hline Mn & 64.5 & 26.6 & 22.5 & 28.8 & \\
\hline $\mathrm{Fe}$ & 1231 & 831 & 808 & 1981 & \\
\hline $\mathrm{Ni}$ & 1.03 & 1.0 & 1.23 & 0.17 & \\
\hline $\mathrm{Cu}$ & 0.12 & & & 0.16 & \\
\hline $\mathrm{Zn}$ & 1.45 & 0.44 & 2.52 & 4.45 & \\
\hline $\mathrm{Pb}$ & & & 0.12 & 0.18 & \\
\hline
\end{tabular}

Source: Martin 1974. 
In an investigation by Geidel (Geidel 1976), the shales from the Pocahontas basin in eastern Kentucky and West Virginia were studied to determine any correlation between rock type and weathering characteristics. Rather than utilizing column leaching experiments, which may or may not simulate actual field conditions, samples of shale were placed in plastic chambers that were continuously purged with humidified air. This experimental design allowed the weathering of the rock samples to proceed under aerobic conditions. Twice a week the samples were leached or rinsed to remove the reaction products that had accumulated since the previous rinse. Records were kept of cumulative alkalinity, cumulative acidity, shale sulfate concentration, shale iron concentration, and shale calcium concentrations over a 60-day leaching period.

Geidel found that all shale samples tested produced alkaline leachates. However, some shale groups demonstrated the potential to produce acid in the future, whereas others would sustain a greater potential for neutralization.

These results are significant for the runoff from shale piles near strip-mine sites, but the real interest, from the point of view of a coal storage pile study, lies in the experimental methods. It may be that laboratory column leaching experiments expose the coal to an excess of water, which does not actually simulate what occurs in a coal storage pile. The volume of water in the column would decrease the amount of oxygen available for the oxidation of coal material. These reasons suggest the necessity of further investigations into the humidified air method of leaching coal samples, and possible experiments designed to compare this method of leaching with column studies. It is obvious that humidified air leaching is not what actually takes place in a large compacted coal storage pile, and this should be taken into consideration when interpreting the data from such experiments.

A problem very similar to coal storage pile leachate, but one which has likewise received little attention, is the water generated from coal slurry pipelines. Figure 4 shows the existing and proposed slurry pipelines in the United States.

Briefly, the idea behind coal slurry pipelines is to mix pulverized coal with water to form a slurry. This slurry is then pumped, at 


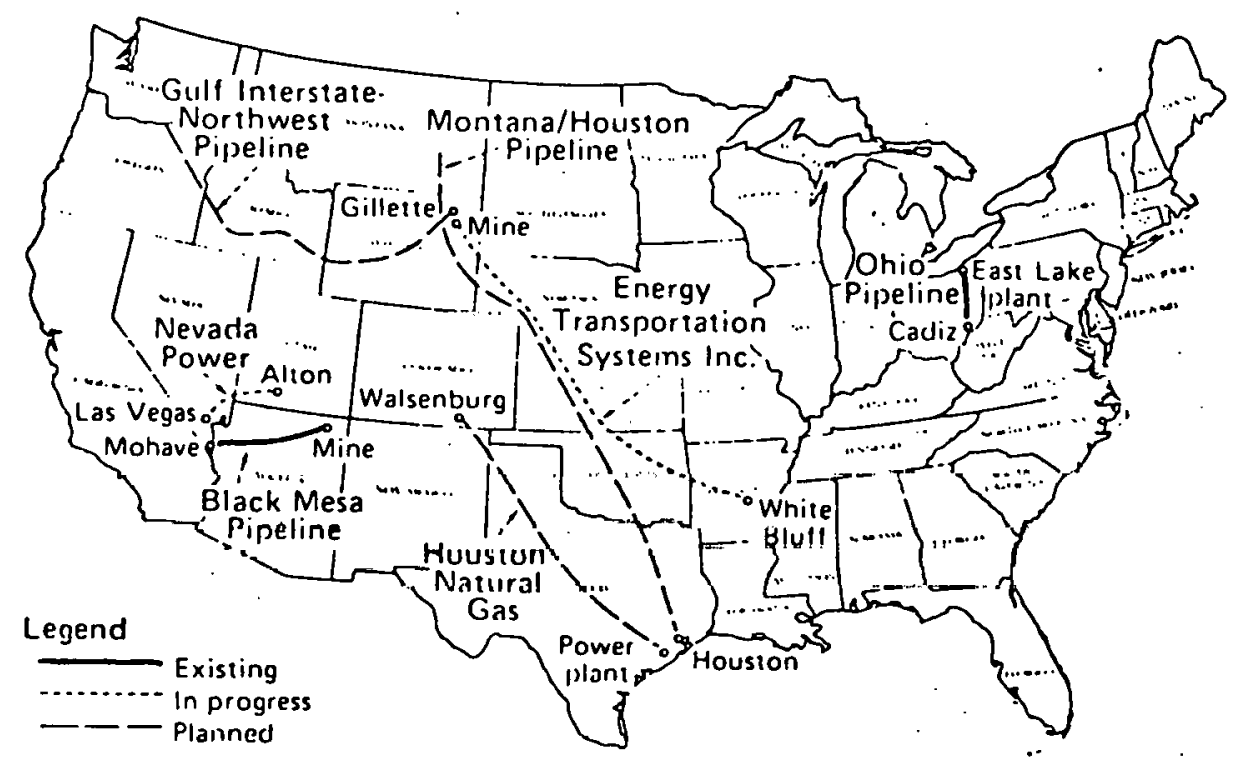

Fig. 4. U.S. proposed and existing coal slurry pipelines. Source: Davis 1976 .

sufficient velocities to inhibit settling of the coal particles, from mines or coal transshipment facilities to existing power generating facilities. The coal is then separated from the water by gravity, vacuum filters, centrifuges, or a combination of the three methods, and the carrier water is disposed of (Cowper et al. 1972, Halloran 1976). The environmental impact of the pipeline itself seems minimal, since the lines are generally underground and equipped with safety drainage ponds in case of a break or leak in the system. The problem, however, arises when the water which has been used to transport the coal must be disposed of. There is no appreciable pickup of dissol.ved solids from the coal as the slurry moves through the pipeline, since. the coal is essentially inert (Wasp et al. 1976). The so-called acid problem, which results in the formation of ferrous sulfate, does not occur in the slurry pipeline context because of the limited availability of oxygen. The small amount of dissolved oxygen in the water, which occurs naturally when the water and slurry are mixed, quickly disappears because the oxygen is adsorbed on the cool surface. This process is completed a few miles down the pipeline; from that point forward the pipeline is in essentially an anaerobic system. 
These findings directly contradict the experimental results published by Metry (Metry 1975), which show that, even under anaerobic conditions, water exposed to coal picks up significant amounts of solids and inorganic elements present in the leached coal.

This potential water quality problem from coal slurry pipelines will become an increasing concern as additional trace element concentrations are added to effluent permits. 
SUMMARY

The previous discussion of work that has been carried out on characterizing coal storage pile leachate shows that the results of experimental analysis differ considerably from one group of researchers to the next. Each researcher has had his own goals in mind, ranging from simply characterizing leachate to designing a treatment system for a coal transshipment facility. Data have been collected under all kinds of experimental conditions and on many different types of coal.

In general, as indicated in the previous section, values obtained for coal pile leachate show a wide variation in chemical and solids concentrations. Many reasons may account for this variability, such as coal type, amount and frequency of rainfall, temperature, and perhaps coal particle size. However, a large amount of the data is from random sampling with fairly sketchy documentation. Very, little comparison of the leachate composition with the chemical composition of the original coal appears to have been performed.

The literature shows that, to date, few investigators have looked at the environmental impact of the leachate from coal storage piles. Most authors present data from the analysis of grab samples taken from leaching experiments, or from on-site sampling during rainfall events, but there has been little concentrated effort to investigate the long-term environmental effects of coal pile leachate with emphasis on changing water quality. 
1. Little information appears to be reported in the literature regarding runoff from coal storage piles. What research has been reported consists mainly of individual grab samples, not sustained or controlled testing, on a number of different coals of undefined composition.

2. Reported data indicate that the composition of coal pile runoff appears to be similar to acid mine drainage from surface and deep coal mining operations. No data was reported on potential attenuation of leachate from coal storage piles by local soils.

3. There appears to be a need for more detailed and systematic studies of coal pile runoff, and the associated attenuation of this leachate by various soil types. Runoff studies should be related to environmental parameters such as biological activity, temperature of the pile, time interval between storm events, depth of leaching, organic-inorganic sulfur content of the coal, and lime content of the soil. 


\section{REFERENCES}

Anderson, W. C., and Youngstrom, M. P., "Coal Pile Leachate - Quantity and Quality Characteristics," J. Sanit. Eng. Div., Am. Soc. Civ. Eng. 102: 1239 (1976).

Braley, S. A., "Acid Drainage from Coal Mines," Am. Inst. Min. Metall. Eng. 190: 703-7 (1951).

Chu, T.-Y.J., Ruane, R. J., and Steiner, G. R., "Characteristics of Wastewater Discharges from Coal-Fired Power Plants," in 31st Annual Purdue Ind. Waste Conf., May 4-6, 1976.

Cowper, N. T., et al., "Processing Steps: Keys to Successful SlurryPipeline Systems," Chem. Eng. 79: 58-67 (February 1972).

Cox, D. B., Chu, T.-Y.J., and Ruane, R. J., "Quality and Treatment of Coal Pile Runoff," paper prepared for presentation at NCA/BCR Coal Conf. and Expo. IV, Louisville, Ky., Oct. 13-20, 1977.

Davis, J. C., "Long Distance Slurry Transport - Finally in the Pipeline," Chem. Eng. 83(9): 67-70 (April 1976).

Energy Research and Development Administration, Annual Environmental Analysis Report, an environmental analysis of energy technologies using the assumptions of the National Energy Plan, Vol. 1, Technical Summary, MTR-7626 (1977).

Energy Research and Development Administration, Coal Research, Development and Demonstration Program, Draft Environmental Impact Statement, ERDA-1557-D (September 1977).

Environmental Protection Agency, Health, Environmental Effects, and Control Technology of Energy Use, EPA-6001 7-76-002 (February 1976).

Fayol, H., Bull. Soc. Ind. Miner. 5(2): 487-746 (1879).

Featherby, S. F., and Dodd, D. J. R., "Control of Air and Water Contaminants from Coal Piles," paper presented at the ASCE Spring Conf., Dallas, Texas (1977).

Federa1 Energy Administration, National Energy Outlook, FEA-N-75/713 (February 1976).

Geide1, G., "A Laboratory Study of the Effect of Carboniferous Shales from the Pocahontas Basin (Eastern Kentucky - West Virginia) on Acid Mine Drainage and Water Quality," M.S. Thesis, Dept. of Geology, Univ. of South Carolina (1976). 
Good, D. M., Ricca, V. T., and Shumate, K. S., "The Relation of Refuse Pile Hydrology to Acid Production," Third Symp. on Coal Mine Drainage Research, Bituminous Coal Research, Inc., Monroeville, Pa. (1970).

Halloran, J. J., "Coal Slurry Dewatering Equipment Maintenance Developments: Techniques and Costs," paper presented at the Slurry Transport Assoc. Annual Meeting, Houston, Texas, August 1976.

Hill, R. D., and Bates, E. R., "Subsidence and Acid Mine Drainage," paper presented to the Committee on Health and Environmental Effects of Increased Coal Utilization, Washington, D.C., November 1977.

Kendrick, P. J., "Acid Mine Drainage - An old Problem with a New Dimension," J. Water PolZut. Control Fed. 49: 1576 (1977).

Mace, G., "Coping with Wastewater Regulations," Power Eng. 81(5): 52-55 (1977).

Martin, J. F., "Quality of Effluents from Coa1 Refuse Piles," paper presented at the First Symposium on Mine and Preparation Plant Refuse Disposal. Coal and the Environment Technical Conf., Oct. 22-24 (1974).

McFal1, R. L., "Coal Pile Leachate - Quantity and Quality Characteristics, a Discussion," J. Sanit. Eng. Div., Am. Soc. Civ. Eng. 103(EE4): 760 (1977).

Metry, A. A., "Treatability and Treatment of Leachate and Contaminated Run-off Waters from a Coal Transshipment Facility," Proc. of the 30th Ind. Waste Conf., Purdue Univ., Ann Arbor Science, 1975.

National Coal Association, "Coal Storage Methods," Fuel Eng. Data published by the NCA, Washington, D.C. (1972).

National Energy Plan, Executive Office of the President, Energy Policy and Planning, U.S. Government Printing Office (1977).

Nichols, C. R., "Development Document for the Proposed Effluent Limitations Guidelines and New Source Performance Standards for the Steam Electric Power Generating Point Source Category," U.S. EPA Pub. No. EPA 440/1-73/029 (March 1974).

Parsons, J. D., "The Effects of Acid Strip-Mine Effluents on the Ecology of a Stream," Arch. Hydrobiology 65: 25-50 (1968).

Rice, J. R., and Strauss, S. D., "Water Pollution Control in Steam Plants," Power 120(4) (1977). 
Roffman, H., and Roffman, A., "Coal Mining and Related Environmental Effects on Land, Afr, and Water," Proceedings of the Institute of Environmental Sciences, Anaheim, Calif., 1975.

Temple, K. L., and Colmer, A. R., "The Formation of Acid Mine Drainage," Am. Inst. Min. Metall. Eng. 190: 1090-92 (1951).

U.S. Coal Development - Promises, Uncertainties, Report to the Congress by the Comptroller General of the U.S., EMD 77-43 (September 22, 1977).

U.S. Government, "Interim Primary Drinking Water Standards," Fed. Regist. 40 (51) (March 1975).

Wasp, E. J., Aude, T. C., and Raymer, F. B., "Terminal Facilities for Western Coal Slurry Pipelines," paper presented at the AIME Annual Meeting, Las Vegas, Nevada, February 1976.

Wewerka, E. M., Williams, J. M., and Wanek, P. L., "As sessment and Control of Environmental Contamination from Trace Elements in Coal Processing Wastes," Proc. Nat1. Conf. Health, Environ. Effects, and Contro1 Techno1. of Energy Use, U.S. EPA Rep. No. 600/7-76-002, p. 226 (1976).

Zubovic, P., Geochemistry of Trace Elements in Coal, U.S.G.S., Reston, Va. (1975). 
ORNL/TM-6186

INTERNAL DISTR.IBUTION

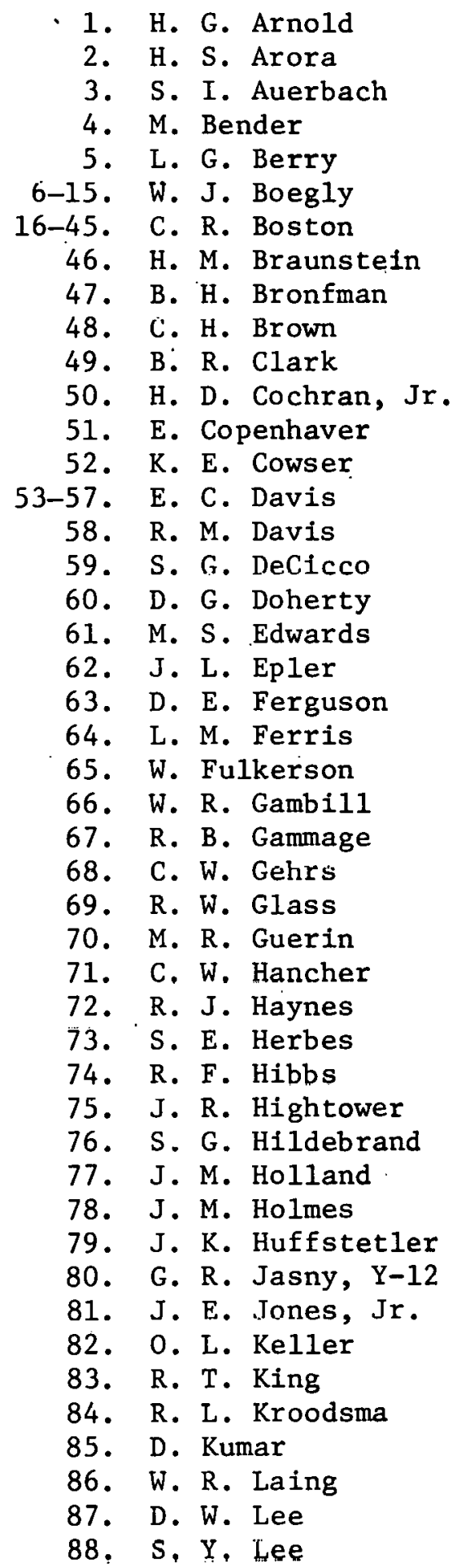

89. W. S. Lyon

90. R. E. MacPherson

91. G. B. Marrow

92. H. A. McLain

93-94. L. E. McNeese

95. J. R. McWherter

96. J. E. Mrochek

97. B. D. Murphy

98. P. Nettesheim

99. J. P. Nichols

100. B. Niemann

101. G. R. Peterson

102. T. W. Picke1

103. H. Postma

104. R. G. S. Rao

105. D. E. Reichle

106. C. R. Richmond

107. L. W. Rickert

108. B. R. Rodgers

109. R. D. Roop

110. M. W. Rosenthal

111. T. H. Row

112. W. L. Russe11

113. M. S. Salk

114. R. Salmon

115. G. Samuels

116. F. S. Sanders

117. C. D. Scott

118. D. S. Shriner

119. W. D. Shults

120. S. P. N. Singh

121. C. B. Smith

122. I. Spiewak

123. R. L. Spore

124. W. P. Staub

125. J. B. Storer

126. E. G. Struxness

127. G. W. Suter

128. T. Tamura

129. H. E. Trammell

130. D. B. Trauger

131. W. C. Ulrich

132. P. R. Vanstrum

133. J. S. Watson

134. J. R. Weir

135. NRML Patent office 
136. Laboratory Records, ORNL-RC

137-141. Laboratory Records Department

142-144. Central Research Library

145. Document Reference Section

\section{EXTERNAL DISTRIBUTION}

DOE-OAK RIDGE OPERATIONS OFFICE, P.O. BOX E, Oak Ridge, TN 37830

146. Research and Technical Support Division

DEPARTMENT OF ENERGY-ASSISTANT SECRETARY FOR ENVIRONMENT, Washington, DC 20545

147. N. F. Barr

148. C. E. Carter

149. C. W. Edington

150. P. House

151. R. M. Jimeson

152. R. A. Lewis

153. J. L. LIverman

154. W. E. Mott

155. M. Schulman

156. D. H. Slade

157. J. Swinebroad

158. R. W. Wood

DEPARTMENT OF ENERGY-ECONOMIC REGULATORY ADMINISTRATION, Washington, DC 20545

159. B. R. House, Assistant Administrator

160. W. Romanek, Director, Division of Coal Ut1lization

DEPARTMENT OF ENERGY-FOSSIL ENERGY, Washington, DC 20545

161. W. Bakker

162. J. D. Batchelor

163. T. Beresovski

164. L. M. Burman

165. F. L. Clark

166. N. P. Cochran

167. 0. A. Cullitti

168. R. C. Corey

169. T. Cox

170. P, Thuamel

171. J. Forst

172. H. Franke1

173. S. I. Freedman

174. D. Garrett

175. W. S. Harmon

176. D. K. Jones

177. H. T. Jones

178. L. Kindley

179. C. Knudsen
180. T. K. Lau

181. W. G. McDaniel

182-187. C. Miller

188. M. Neuworth

189. E. S. Pierce

190. H, E. Podall

191. J. L. Powell

192. M. Rellly

1.93. J. Shen

194. A. P. Sikri

195. J. Smith

196. D. K. Stevens

197. W. E. Warnke

198. J. W. Watkins

199. H. L. Weisenfeld

200. D. O. Webb

201-202. P. R. Weiber 
203. Jack L. Durham, Environmental Protection Agency-Research Triangle Park, Durham, NC 27711

204. S. David Freeman, Director, Tennessee Valley Authority, 400 Commerce Avenue, Knoxville, TN 37902

205. Rene H. Males, Director, Energy Systems, Environment and Conservation Division, Electric Power Research Institute, 3412. Hillview Avenue, P.0. Box 10412, Pạlo Alta, CA 94303

206. David J. Rose, Department of Nuclear Engineering, Room 24-210, Massachusetts Institute of Technology, Cambridge, MA 02139

207. David Dutlweiler, Director, S. E. Research Laboratory, Environmental Protection Agency, Athens, GA 30603

208. Walter Sanders, Associate Director, S. E. Research Laboratory, Environmental Protection Agency, Athens, GA 30603

209. Dr. Steven Reznek, Office of Energy, Minerals and Industry, Environmental Protection Agency, Washington, DC 20460

210. V. Kerry Smith, Resources for the Future, 1755 Massachusetts Avenue, NW, Washington, DC 20036

211. Macauley Whiting, Vice President, The Dow Chemical Company, 2020 Dow Center, Midland, MI 48640

212. F. L. Parker, Environmental Engineering, Vanderbilt University, Nashville, TN 37235

213. E. L. Thackston, Environmental Englneering, Vanderbilt University, Nashville, TN 37235

214. R. Rowe, Environmenta1 Engineering, Vanderbilt University, Nashv111e, TN 37235

215. Dennis Weeter, Civil Engineering, University of Tennessee, Knoxville, TN 37916

216-242. Technical Information Center, DOE, P.0. Box 62, Oak Ridge, TN 37830 